suggestion and determine the probable error of each experimental result? Each result could then be expressed by a circle the radius of which is equal to half the probable error, and which would increase with the size of the diagram. If another experiment be made under similar conditions it is about an equal chance that it falls within or without the circle, which therefore affords a measure of the precision of the observations. Since there is little evidence against any curve which cuts the circle, the variations in size might profoundly modify the opinion of the draftsman as to the direction of his curve.

SYDNEY LuPton.

\section{Ground Rainbows.}

I HAVE seen with pleasure Mr. Heath's clear and instructive letter and diagrams on this subject in NATURE of March 2. Some fourteen years ago I calculated the altitudes of the sun required to produce the elliptic and other arcs, and obtained results in agreement with Mr. Heath's, except that I took $4 \mathrm{I}^{\circ}$ instead of $42^{\circ}$ for the semi-angle of the cone.

For Petersfield, at II a.m. on October I4, I9I5, the sun's altitude, $23^{\circ}$, appears to be somewhat underestimated, and I make it just above $30^{\circ}$, but this, of course, leaves the bow still hyperbolic.

I was led to consideration of the curves for the ground rainbow when seeking for a reason why the sky rainbow is seen always circular, though, when the sun is not on the horizon, the bow might perhaps have been expected to appear elliptical, the circle being projected into an ellipse on a plane perpendicular to a sight-line, assumed horizontal.

I came to the conclusion that, there being no definite plane of reference in the sky, and the rays being parallel, there is, as it were, no element of definite distance involved, so that the sky bow always appears circular. But for the ground bow we have a definite horizontal plane of reference, so that this bow becomes a conic section, varying with the sun's altitude.

I had some interesting correspondence at the time with the late Sir G. G. Stokes, and I may perhaps quote from one of his letters, dated August 22, I902, only six months before his death. Replying to my question as to whether a dew bow is seen as a circle or an ellipse, he wrote :-

"It is a question of the combination of sensation and expectation. In a dew bow we are impressed with the idea that the luminosity we see is spread over a horizontal plane; and we tacitly ask ourselves the question: What must be the actual form of the locus of the drops on the grass in order that the luminosity may appear as it does? The answer, of course, is, an ellipse, or it might be an hyperbola. If the question be: As what do we see the bow? the answer depends on a combination of sensation with interpretation of sensation. If we merely saw the luminosity, and knew absolutely nothing about its history, we should never think of anything but circularity about it."

I have often looked for a ground bow, but have never been fortunate enough to see one.

Observing a fine lunar rainbow on January 2 I, I found the light to be polarised in planes passing through the point looked at and the radius at the point, just as is the case with the solar rainbow. I hope that Mr. Heath will test the next ground bow with a Nicol prism.

Invermay, Hyde Park, Leeds, March 3 .

IN the Proceedings of the Royal Society of Edinburgh, vol. vii. (1869-70) Clerk Maxwell has a short note on a bow seen on the surface of ice. This was observed on January 26,1870 , on the frozen surface of the ditch which surrounds St. John's College, Cambridge. Maxwell remarks, "How a drop of water can lie upon ice without wetting it and losing its shape altogether I cannot profess to explain." In 1898, in vol. xxii. of the same Proceedings (1898) there is a note on dew bows by Dr. R. A. Lundie and myself. These were produced at night on the ground, the source of light being the gas lamp or electric light of the street. $A$ short account will be found in NaTure of January 12, I899 (vol. lix., p. 263).

Royal Society, Edinburgh, March 4. C. G. Knotr.

\section{Science and the State.}

Referring to Prof. Cohen's letter in Nature of March 2, it may not be untimely to cite another paragraph written in $183 \mathrm{I}$ re neglect of science in this country. Sir David Brewster, in his "Life of Newton," published in that year, says :-

"But what avails the enthusiasm and efforts of individual minds in the intellectual rivalry of nations? When the proud science of England pines in obscurity, blighted by the absence of the royal favour, and of the nation's sympathy-when its chivalry fall unwept and unhonoured-how can it sustain the conflict against the honoured and marshalled genius of foreign lands?"

The position to-day is fortunately not quite so bad as here indicated by Brewster, but is it not still the case that, in the words of Sir Archibald Geikie, science rests under an incubus of apathy and indifference? Expansion of science and national evolution are two matters that in the opinion of the writer are intimately bound up one with the other. Neglect of the former really means inhibition of political progress.

David Balsillie.

Greyfriars Garden, St. Andrews, March 4.

\section{THE NATIONAL IMPORTANCE OF THE DYE INDUSTRY.}

$A^{T}$ the annual meeting of the Bradford Dyers' A Association held on February 28 the chairman of the directors, Mr. Milton S. Sharp, made a highly interesting statement on the national position with regard to the supply of dyes. He described with great force and clearness the close connection between the manufacture of dyes and high explosives, and pointed out how Germany by reason of her huge, highly organised, and ably administered colour works, producing all the raw materials for the making of high explosives, was able immediately to divert much of their plant to war purposes. He paid a high tribute to Lord Moulton and the High Explosives Department for their services, the value of which, he said, the country will probably never know, in improvising the manufacture of high explosives. He urged that whatever it involves, we must establish the aniline dye industry in this country, so that in case of war we may have the ability to produce quickly any amount of high explosives the Army or Navy may need. The extensions of plant that have been made for the temporary purpose of manufacturing high explosives will, he says, make a long and essential step towards the colour industry, and to break them up after the war would be little short of criminal folly. Mr. Sharp quoted some effective examples of German activity in relation to the chemical service of the war. He alluded to one 